Beyond Philology No. 17/3, 2020

ISSN 1732-1220, eISSN 2451-1498

https://doi.org/10.26881/bp.2020.3.03

\title{
Layout changes in the textbook for learning English and their influence on the dyslexic students' work effectiveness - an eye-tracking analysis
}

\author{
AGNIESZKA ANDRYCHOWICZ-TROJANOWSKA
}

Received 16.06.2020,

received in revised form 22.11 .2020

accepted 24.11.2020.

\begin{abstract}
The aim of the following article is to present the results of the second part of an eye-tracking study conducted on Polish secondary school students working with a textbook for learning English. Because of the fact that almost every group of school students consists of both dyslexic and non-dyslexic ones and that all of them use the same textbooks, we wanted to examine if we can adjust the textbook for learning English in such a way as to influence (i.e. improve) the way the students work with it. To check it we used a real-existing layout of a textbook page and its changed version and checked how dyslexic and nondyslexic students worked with them.

In the article we present the eye-tracking parameters for so called areas of interest as well as correctness of the answers which is a nonoculomotor parameter.
\end{abstract}

\section{Keywords}

textbook, English, school student, eye tracker, fixation, area of interest, layout, dyslexia 


\title{
Zmiany układu w podręczniku do nauki języka angielskiego $i$ ich wplyw na efektywność pracy uczniów z dysleksja - analiza okulograficzna
}

\begin{abstract}
Abstrakt
Celem niniejszego artykułu jest przedstawienie wyników drugiej części badania okulograficznego przeprowadzonego wśród polskich licealistów pracujących $z$ podręcznikiem do nauki języka angielskiego. Ze względu na to, że prawie każda grupa uczniów składa się zarówno $z$ osób $z$ dysleksja, jak i bez dysleksji i wszyscy korzystaja z tych samych podręczników, chcieliśmy sprawdzić, czy potrafimy dostosować podręcznik do nauki języka angielskiego w taki sposób, aby wpłynąć na (tj. poprawić) sposób, w jaki uczniowie $z$ nim pracują. Aby to sprawdzić wykorzystaliśmy istniejacy układ strony podręcznika i jego zmienioną wersję oraz sprawdziliśmy, jak pracuja $z$ nimi uczniowie $z$ dysleksją i bez dysleksji.

W artykule przedstawiamy parametry eyetrackingu dla tzw. obszarów zainteresowań oraz poprawność odpowiedzi, która jest parametrem nieokulomotorycznym.
\end{abstract}

\section{Słowa kluczowe}

podręcznik, angielski, uczeń, okulograf, fiksacja, obszar zainteresowania, układ graficzny, dysleksja

\section{Introduction}

Despite the fact that modern school student groups are relatively strongly differentiated in terms of special educational needs, all of them use the same textbooks for learning a foreign language, and very often these textbooks do not take into account these special educational needs. In almost all cases, the teaching and learning properties of textbooks are subordinated by publishing houses to visual appeal. The effectiveness of textbooks is negatively affected by this situation, and thus the students using these textbooks suffer, and in particular the students with developmental dyslexia. In fact, the problem is even 
more complex. It does not concern only textbooks for learning English or other languages. Also in other areas, one can notice the lack of indepth scientific reflection on the conditions of acquiring knowledge based on textbooks by students with dyslexia.

\section{Scope of our interest - textbook and dyslexia}

Our research interests are related to the textbooks for learning English used in the Polish secondary schools. We are interested in their layout and its influence on the visual behaviour of their users, i.e. students. The problem is the users are not a homogenous group and in our studies we are mainly interested in those with special educational needs narrowed down to developmental dyslexia.

Developmental dyslexia, or specific difficulties in reading and writing (with simultaneous proper mental development), is more and more often being diagnosed in Polish school students. Dyslexia is often accompanied by difficulties in writing (dysgraphia) and correct spelling (dysortography). Dyslexia can also be combined with dysphasia (a speech development disorder in children), dyscalculia, dyspraxia (lack of physical coordination), with problems related to keeping track of time, with issues linked to spatial and directional orientation, motor hyperactivity or attention disorders, etc. Developmental dyslexia has a neurobiological background and is associated with the structure and functioning of the brain (Habib 2000).

The process of learning English at school is usually accompanied by the use of textbooks for learning English. These textbooks are visually very attractive. However, a school textbook should be clear and readable. Clarity is influenced by the contrast between the letters and the background, as well as the type of paper and print quality, whereas readability depends on the typeface and size of letters, the density of the written text on individual pages (related to space), the width of the lines, the distance between the lines (spacing), the boldness and the colour of letters. Printed text should have a uniform font size, the same line length and margin width, optimal line spacing, perfect composition, good print quality, correct paper whiteness (guaranteeing good paper and print contrast), and text compliant with the principles of safe and effective reading. The textbook should use a uniform typeface and the same font size, avoiding the use of italics, etc. The layout of illustrations and tables on the textbook page is also important (Hanisz 
2005: 469). Unfortunately, the big group of textbooks for learning English used in Polish secondary schools does not comply with these hints.

The point is the above hints related to textbook layout are especially important in the case of dyslexic students. To check how we can improve their perception of the material from the textbook for learning English we decided to check their eye movements with the aid of an eye tracker.

\section{Eye tracking}

Eye tracking allows to observe and analyse the way a subject looks at an object. It makes it possible to see in details what is at the centre of someone's gaze as well as to follow the path as the visual attention of the subject wanders (Duchowski 2007: 3). Because eye trackers are advanced physiological systems of measurements (Holmqvist et al. 2011: 11), they track and record the position of where the eye is looking at and in what order. It allows to identify the areas which are brought to the participant's attention. Modern video-based eye trackers register eyeballs movement with the aid of the camera directed at the eyes and the measuring system integrated with the computer and it allows to identify the areas which are brought to the participant's attention (Holmqvist et al. 2011, Duchowski 2007).

There are two basic eye movements, i.e. fixations and saccades. Fixations stabilise the retina over an object of interest which is stationary (Duchowski 2007: 46). They are moments when our eyes focus on a particular object lasting approximately 200-300 milliseconds. Saccades are rapid eye movements occurring between fixations and lasting, depending on a source, $40-50 \mathrm{~ms}$ (Lorigo et al. 2008) or 30$80 \mathrm{~ms}$ (Holmqvist et al. 2011). They reposition the fovea to a new location (Duchowski 2007). During a saccade the eyes move very fast (the velocity can be even $500^{\circ}$ per second) and because of this no new information is obtained during a saccade (Rayner, 1998).

Areas of interest (AOIs) are the regions in the stimulus (i.e. material that is the subject of the eye-tracking research and is presented on the computer screen) that the researcher is especially interested in gathering data about (Holmqvist et al. 2011: 187). The participant does not see the AOIs on the stimulus. They are chosen by the researcher and can be changed and/or selected during the analysis of the data. They are also used to include or exclude some parts of the stimulus from the further analysis. 


\section{Methodology}

Our eye-tracking study on textbooks for learning English consisted of two parts, both being conducted as the "Kształtowanie kompetencji językowych u uczniów $z$ dysleksja rozwojowa" [Developing language competences in secondary school students with developmental dyslexia] project (financed by the Ministry of Science and Higher Education, research grant No. 206428/E-343/S/2017-1 of 12.12.2017). The first part of the project was described in details in Andrychowicz-Trojanowska 2018 and is of no direct interest in the following article. The article is devoted to the results of the second part which was conducted by the following team: S. Grucza (head), A. Andrychowicz-Trojanowska, K.M. Bogdanowicz, K. Wiejak, and M. Płużyczka.

\subsection{Material and data acquisition}

The above mentioned second part of the project was conducted between June and November 2018 in Gdansk on 40 secondary school students, both dyslexic (20) and non-dyslexic ones (20). By "dyslexic students" we mean those who had an official certificate from psychological-pedagogical counselling centres confirming their dyslexia. The participants were the students of all three grades of the secondary school.

The place of the eye-tracking study was the school. There were two materials (hereinafter called sets) the participants worked with. The participants were randomly divided into two equal groups, each consisting of 10 dyslexic and 10 non-dyslexic students, working with one of two sets. The sets (set 1 and set 3 - the numbering is related to the one from the first part of the study, described in AndrychowiczTrojanowska 2018; they were an example of the textbook page) the students worked with were shown on a computer screen. There was also a questionnaire in the written form that was given after completing the tasks (a participant had a chance to write down any of his/her opinions that could be helpful when analysing the research results the questionnaire answers are, however, of no interest in this article). Both materials together with seven areas of interest each (four pictures: photo 1 , photo 2 , photo 3 , photo 4 ; three boxes: box 1 , box 2 , box 3) are shown in Figures 1 and 2. 


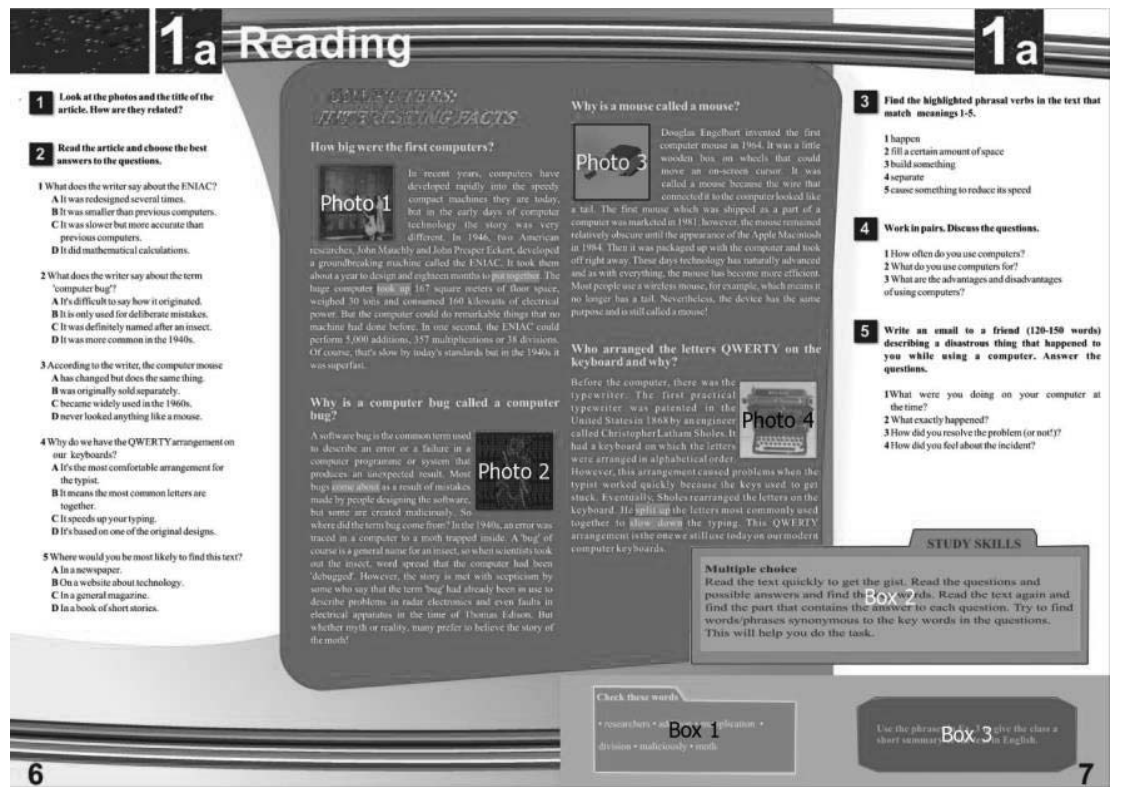

Figure 1

Set 1 with AOIs. Source: own

\section{1a Reading}

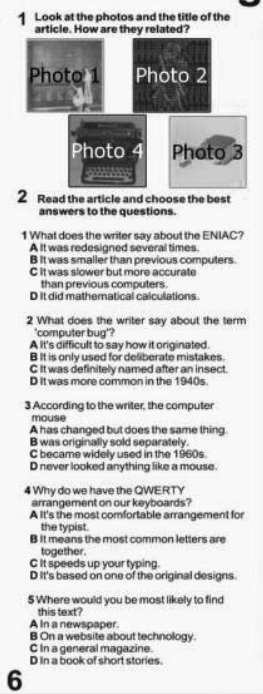

COMPUTERS:
INTERESTING FACTS

How big were the first computers?

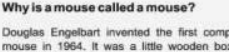

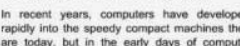

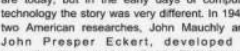
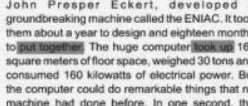

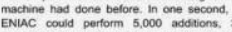

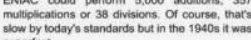
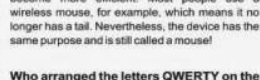

Who arranged the leters OWERTY on the
heyboard and why

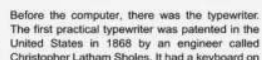

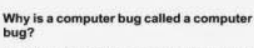

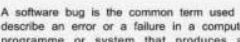
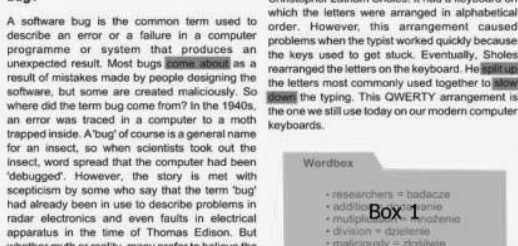

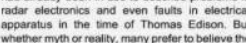

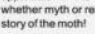
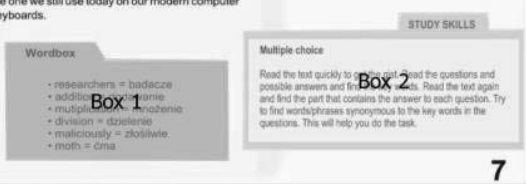

Figure 2

Set 3 with AOIs. Source: own 
It should be emphasised that the content of the language learning material in both sets was the same, but the colours used, the location of pictures and the location and content of three boxes. Set 1 mirrored a real-existing textbook for learning English. In set 1, the pictures were located within the paragraphs of the text. There were also three boxes located in the lower right-hand corner of the page. Box 1 (titled Check these words) was located rather far from the text although it was related to it. In box 1, there were 6 words occurring in the text that were more difficult to understand. What is important, they were given only in their original, English, form, with no explanation of their meaning. The aim of box 1 was to draw student's attention to these words and encourage the student to check their meaning in a dictionary (that is why no explanation to them was given). Box 2 was titled Study Skills and was a short set of hints on how to complete the single choice task (the students were to complete such a task) as to be the most successful. Although box 2 was not directly related to the text, it was situated the closest to it. Box 3 is a separate oral activity and is related to exercise 3 (the latter one should be completed first). Its content was not related anyhow to the text but it was presented in the graphically visible way in the original textbook (it was a separate graphic element there).

In set 3 , the colours of the textbook page were changed and their variety was limited according to the suggestions given in the literature (Evans 2001, Bogdanowicz 2011, Mitchell and Wightman 2012, Pollak 2012 , etc.), and the pictures were moved from the text area and placed in exercise 1 (they were a part of it). What is more, box 3 was removed and moved to exercise 6 . Box 2 was made a bit smaller and moved to a new location, and box 1 changed its size a bit, location (it was moved closer to the text area) and content (the Polish equivalents to the English words from the box were added, as well as shape and colours were changed).

The types of exercises the students were asked to complete were the same in both sets: exercise 2 on page 6 was a single choice task (students were to read the text and choose a proper ending/answer to five sentences/questions out of four possibilities given) and exercise 3 on page 7 consisted in matching the definitions given there with the words highlighted in the text (the maximum number of points in every task was 5 , so a participant could get 10 points altogether).

The participants' eye movements were recorded with an SMI RED 500 eye-tracking system with a sampling rate of $250 \mathrm{~Hz}$. The 
participants sat in front of a 22-inch LCD monitor (equipped with a mini video camera, i.e. an eye tracker, placed just under it) at a distance of about $60 \mathrm{~cm}$. The average tracking ratio (i.e. the proportion of time the eye tracker recorded point-of-gaze coordinates during the task - Amso et al., 2014, p. 2) was $97 \%$ for the whole study (set $1=$ $96.41 \%$, set $3=97.61 \%$ ) with a standard deviation of $2.63 \%$ (set $1=$ $3.29 \%$, set $3=1.52 \%)$. The recorded data was analysed with the aid of BeGaze 3.7 analysis software and IBM SPSS Statistics (version 25).

When calibration had been completed, the set was displayed on the computer screen and the student heard the task to complete exercise 2 on page 6 . When it was done, the second task (to complete exercise 3 p. 7) was given. There was no time limit. At the end of the study the participants were asked to fill in the questionnaire related to the study.

\subsection{Hypothesis and eye-tracking metrics}

We hypothesise that a proper design of a textbook page improves the way the secondary school students (especially those suffering from dyslexia) work with the textbook material. By the proper design of the textbook we understand here a design that is adjusted to the needs of dyslexic students related to fonts, colours used, location of different parts of the material etc., as it is suggested in the literature (Evans 2001, Bogdanowicz 2011, Mitchell and Wightman, 2012, Pollak 2012 etc.).

To verify the hypothesis we chose the set of parameters that will be compared between the particular AOIs and two sets of materials, and between participant groups (dyslexic and non-dyslexic ones). The set of parameters consists of the group of five eye-tracking metrics for the AOIs, i.e. entry time, first fixation duration, fixation count, dwell time and revisits. There is also one non-oculomotor parameter that is of our interest, i.e. correctness of the answers. Entry time is the duration of the time before the first fixation in the area of interest (AOI). First fixation duration is the duration of the first fixation at a particular AOI and it reflects the time taken to recognise and identify a part of the stimulus image, processes which are extremely fast (Holmqvist et al. 2011). Fixation count is the number of fixations in each trial (in a particular AOI) correlated to total dwell time (Holmqvist et al. 2011). It is said to be the most often used parameter in eye-tracking research (Jacob and Karn 2003). The higher the number of fixations (overall 
fixations), the poorer the search capacity of a participant or the poorer the structure of the stimuli. On the other hand, more fixations on a particular AOI may indicate that the AOI is more important and/or more noticeable to the participant than the others (Poole et al., 2004). Dwell time is one visit (measured from entry to exit) to an AOI. This is a sum of all the fixations and saccades in a particular AOI (Holmqvist et al. 2011). In other words, it is the total amount of time spent looking within a particular AOI (Tullis and Albert 2013). Revisits are a transition to an AOI that has already been visited (Holmqvist et al. 2011), therefore they are a second and further glance at a previously viewed object (AOIs).

In our case the two sets being the imitation of a textbook page combine both textual and visual information. Very often it happens that the visual one is a kind of a distractor.

\section{Results}

The data are presented in two sections. The first one (5.1) is devoted to five above mentioned eye-tracking parameters in relation to the areas of interests; the second one (5.2) shows non-oculomotor data, i.e. correctness of the answers.

Because of the small number of participants in the second part of our study and relatively high values of standard deviation for eyetracking parameters (not presented in the following article), the results only show some tendencies that ought to be checked on the bigger group of participants.

\subsection{AOIs}

According to our hypothesis, the changes in the layout of set 3 in comparison to set 1 should influence the visual attention of the students. Their aim was to change the layout in such a way as to improve the spread of visual attention in the case of dyslexic students and not to disturb it in the case of non-dyslexic ones. The introduced changes were related to the colours used, but also to location of the photos and boxes. 
Table 1

Eye-tracking index entry time [s] for dyslexic and non-dyslexic participants in the areas of interest. Source: own

\begin{tabular}{|c|c|c|c|c|}
\hline \multirow{2}{*}{ Area of interest } & \multicolumn{2}{|c|}{$\mathrm{D}$} & \multicolumn{2}{c|}{ ND } \\
\cline { 2 - 5 } & $\mathrm{S} 1$ & $\mathrm{~S} 3$ & $\mathrm{~S} 1$ & $\mathrm{~S} 3$ \\
\hline Photo 1 & 12.10 & 56.44 & 16.61 & 69.88 \\
\hline Photo 2 & 215.98 & 110.81 & 194.02 & 1.91 \\
\hline Photo 3 & 124.34 & 79.13 & 169.38 & 60.01 \\
\hline Photo 4 & 342.16 & 3.75 & 296.19 & 2.38 \\
\hline Box 1 & 311.90 & 190.02 & 364.78 & 296.67 \\
\hline Box 2 & 269.96 & 344.93 & 353.11 & 165.34 \\
\hline Box 3 & 185.56 & 308.71 & 319.31 & 80.543 \\
\hline
\end{tabular}

Note: $D-$ dyslexia, $N D-$ no dyslexia, $S 1-\operatorname{set} 1$, S3 - set 3.

We first examined the differences in the entry time, i.e. the duration of the time needed for the first fixation in a particular AOI. It should be reminded that the shorter entry time, the more visually attractive (for many different reasons) the particular AOI. Our prediction was that there would occur the difference in the case of four photos and of three boxes in favour of set 3 . The entry time data is shown in Table 1.

In the case of four pictures big differences can be noticed as the change of their location in set 3 (i.e. moving them from the text area into the upper left-hand corner of the set 3 ) resulted in longer entry time in the case of photo 1 in both groups of participants, i.e. dyslexic and non-dyslexic ones. In the case of photo 2 and 3 the entry time became shorter and in the case of photo 4 there was very small time value in set 3 . That means the changes to the location of the pictures resulted in relatively shorter time needed to notice them. The explanation of that can be the new location of them, i.e. the very left-hand upper corner of the page in set 3. It is known that for example web users direct their eyes exactly into that part of the screen first (Hotchkiss et al. 2005, Nielsen 2006, Hotchkiss 2007).

The changes related to the location and appearance of the three boxes were introduced to draw more attention of the participant to box 1 that contained useful information (that can be helpful especially for dyslexic students), as well as decrease it on two other boxes. In both 
groups of participants the entry time on box 1 turned out to be shorter in set 3 which means box 1 was noticed faster. It may be related to the fact that set 3 was less graphically attractive to the participants and that is why they were faster to notice anything different. In the case of boxes 2 and 3 in set 3 it is seen that dyslexic students needed more time to notice them than non-dyslexic ones and in set 3 their entry time was longer than in set 1.

The first fixation duration (FFD) is directly proportional to the level of interest in a particular AOI (there may be different reasons for this interest). The data on FFDs is presented in Table 2.

Table 2 shows that in the case of all the participants the average FFD is shorter for every photo in set 3 than in set 1 - there is no such correlation in the case of dyslexic students only for photo 4 . The reason of that may be the location of photo 4 in set 3 - it was placed just above the task to exercise 2 (in the middle of it) that the students were to complete. Dyslexic participants might have looked at the photo 4 while reading the task. Longer FFDs on box 1 in set 3 for dyslexic participants should also be emphasised (in set 3, box 1 was located closer to the text that was read and its design as well as the content were modified).

The changes in the form or the location of the boxes 2 and 3 in set 3 resulted in the decrease of FFDs. That means they became less visually attractive and that was the goal of the changes. However, in set 3 the change to box 3 resulted in a slight increase in FFDs in the group of dyslexic students.

The fixation count shows the average number of fixations in the particular AOIs and is presented in Table 3.

The data as presented in Table 3 show two very important tendencies in set 3 , i.e. a decrease in the fixation count for the photos (but photo 4 in the case of dyslexic students), box 2 and box 3, and a significant increase of the fixation count for box 1 . In the case of the photos, it is noticeable in both groups of participants, i.e. dyslexic and non-dyslexic ones, that placing the photos within the text (set 1) is unfavourable from the point of view of fixation count. Such a location helps increase the visual attention paid to them and especially dyslexic students are susceptible to it. These are, though, dyslexic students who easily deconcentrate in, among others, such a way. The consequence of all this may be greater distraction, inattention, losing the thread etc. and that may result in the task being completed less well. 
On the basis of all this, it seems that the best location for the photos is to remove them from the text to be read, as it was done in set 3 .

Table 2

Eye-tracking index of first fixation durations [s] for dyslexic and nondyslexic participants in the areas of interest. Source: own.

\begin{tabular}{|c|c|c|c|c|}
\hline \multirow{2}{*}{ Area of interest } & \multicolumn{2}{|c|}{$\mathrm{D}$} & \multicolumn{2}{c|}{$\mathrm{ND}$} \\
\cline { 2 - 5 } & $\mathrm{S} 1$ & $\mathrm{~S} 3$ & $\mathrm{~S} 1$ & $\mathrm{~S} 3$ \\
\hline Photo 1 & 0.16 & 0.09 & 0.19 & 0.16 \\
\hline Photo 2 & 0.26 & 0.13 & 0.20 & 0.09 \\
\hline Photo 3 & 0.21 & 0.12 & 0.20 & 0.10 \\
\hline Photo 4 & 0.16 & 0.20 & 0.19 & 0.11 \\
\hline Box 1 & 0.16 & 0.25 & 0.20 & 0.15 \\
\hline Box 2 & 0.38 & 0.18 & 0.29 & 0.07 \\
\hline Box 3 & 0.05 & 0.06 & 0.20 & 0.04 \\
\hline
\end{tabular}

Note. $D$-dyslexia, $N D-$ no dyslexia, $S 1-$ set $1, S 3-$ set 3 .

Table 3

Eye-tracking index of fixation counts for dyslexic and non-dyslexic participants in the areas of interest. Source: own.

\begin{tabular}{|c|c|c|c|c|}
\hline \multirow{2}{*}{ Area of interest } & \multicolumn{2}{|c|}{$\mathrm{D}$} & \multicolumn{2}{c|}{ ND } \\
\cline { 2 - 5 } & $\mathrm{S} 1$ & $\mathrm{~S} 3$ & $\mathrm{~S} 1$ & $\mathrm{~S} 3$ \\
\hline Photo 1 & 8.4 & 2.3 & 9.9 & 1.9 \\
\hline Photo 2 & 5.9 & 2 & 4.1 & 1.8 \\
\hline Photo 3 & 10.8 & 1.4 & 11 & 1.3 \\
\hline Photo 4 & 2.7 & 4.9 & 4 & 1.6 \\
\hline Box 1 & 3.8 & 23.6 & 4.3 & 17.3 \\
\hline Box 2 & 18.5 & 6.8 & 13.4 & 1.7 \\
\hline Box 3 & 1.9 & 1.8 & 1.5 & 0.4 \\
\hline
\end{tabular}

Note: $D$-dyslexia, $N D$ - no dyslexia, $S 1-$ set 1, S3 - set 3 . 
What is more, the changes made to the parameter for box 1 should be emphasised. In set 3 , box 1 was moved closer to the text and its content was modified in such a way so as to make it more useful for the students, especially those dyslexic ones. All these changes caused that in set 3 the fixation count on box 1 sharply increased in both groups of participants. Moreover, it seems that placing the photos outside the text caused the change of the visual attention destination - in set 3 the only graphic element in this area is box 1 and only it draws the visual attention there. On the basis of that it can be concluded that it is possible to consciously steer and control students' attention through proper location of different parts of their textbook material.

It should also be noticed that there was a significant decrease in the number of fixations on two other boxes, especially box 2. Data for box 2, however, proves the observation from the first part of the project (Andrychowicz-Trojanowska 2018) about the importance of consciously locating the parts of any material - the further something is from the text to be read, the fewer fixations on it. This is a very important conclusion - the difference in the number of fixations on box 2 in set 1 (in the group of dyslexic and the group of non-dyslexic students) is rather big, as the dyslexic ones fixated 1.3 times more that the non-dyslexic ones.

In set 3 , box 3 was changed into an ordinary exercise, presented in a standard form that was identical with the rest of the activities. The consequence was a decrease in the number of fixations on it. This decrease further proves the conclusion that has already been made about the need for conscious use of graphic elements and colours in the textbooks. There is no need to highlight the parts that are not of major importance on a particular textbook page (this is the case with box 3 -its content was just a task to be completed orally). Eye-tracking data show that such highlighting is the reason for the student's distraction. In the case of dyslexic students it can aggravate their inattention and distraction, which is what should be avoided.

Data on dwell time confirms the previous observations and is shown in Table 4. 
Table 4

Eye-tracking index of dwell time [s] for dyslexic and non-dyslexic participants in the areas of interest. Source: own.

\begin{tabular}{|c|c|c|c|c|}
\hline \multirow{2}{*}{ Area of interest } & \multicolumn{2}{|c|}{$\mathrm{D}$} & \multicolumn{2}{c|}{ ND } \\
\cline { 2 - 5 } & $\mathrm{S} 1$ & $\mathrm{~S} 3$ & $\mathrm{~S} 1$ & $\mathrm{~S} 3$ \\
\hline Photo 1 & 1.87 & 0.53 & 2.94 & 0.35 \\
\hline Photo 2 & 1.96 & 0.50 & 0.86 & 0.33 \\
\hline Photo 3 & 3.39 & 0.48 & 3.23 & 0.20 \\
\hline Photo 4 & 0.59 & 1.26 & 0.85 & 0.31 \\
\hline Box 1 & 0.92 & 8.10 & 1.01 & 4.81 \\
\hline Box 2 & 6.18 & 2.25 & 3.77 & 0.33 \\
\hline Box 3 & 0.44 & 0.69 & 0.39 & 0.09 \\
\hline
\end{tabular}

Note. $D$-dyslexia, $N D$ - no dyslexia, $S 1-$ set 1 , S3 - set 3 .

In set 1 , dwell time, i.e. the sum of all fixations and saccades, in a particular AOI in the group of dyslexic students was definitely the longest for box 2 and then for photo 3 . In the case of non-dyslexic ones, the dwell time on box 2 and photo 3 was the longest, too, but at the same time it was definitely shorter on box 2 in comparison to that for dyslexic students. This means the latter group was more susceptible to looking at these two graphic elements. It should be remembered that the interest in photo 3 was definitely influenced by its location (the upper left-hand corner of the third paragraph, so it was surrounded by the text from 3 of its 4 sides - such a location for the picture increases the probability of focusing one's eyes on it).

For the photos in the sets, the dwell time was shorter in set 3 in the case of non-dyslexic and dyslexic students (but photo 4 in their case). This may be a reason to conclude that the photos were the most visually attractive thing in set 1 , which was very colourful itself; they were least attractive in set 3 where the photos were located outside the text area. In set 3 , dwell time was slightly longer in the case of dyslexic students and photo 4 located in the upper left-hand corner of the set.

The last oculomotor parameter is the revisit count (Table 5). 
Table 5

Eye-tracking index of the revisit count for dyslexic and non-dyslexic participants in the areas of interest. Source: own.

\begin{tabular}{|c|c|c|c|c|}
\hline \multirow{2}{*}{ Area of interest } & \multicolumn{2}{|c|}{$\mathrm{D}$} & \multicolumn{2}{c|}{ ND } \\
\cline { 2 - 5 } & $\mathrm{S} 1$ & $\mathrm{~S} 3$ & $\mathrm{~S} 1$ & $\mathrm{~S} 3$ \\
\hline Photo 1 & 5.4 & 1.4 & 7 & 0.5 \\
\hline Photo 2 & 3.7 & 1 & 2.6 & 0.9 \\
\hline Photo 3 & 7.3 & 0.8 & 7.6 & 0.3 \\
\hline Photo 4 & 1.4 & 2.4 & 2.7 & 0.9 \\
\hline Box 1 & 1 & 7.5 & 1.9 & 4.9 \\
\hline Box 2 & 7.2 & 2.1 & 5.9 & 0.6 \\
\hline Box 3 & 0.5 & 0.5 & 0.2 & 0.2 \\
\hline
\end{tabular}

Note: $D$-dyslexia, $N D$ - no dyslexia, $S 1-$ set $1, \mathrm{~S} 3-$ set 3 .

In set 1 , the biggest number of revisits was for photo 3 in both groups of participants. A similar thing happened with photo 1 . When comparing the data for all the photos, it is easily noticeable that the smallest average number of revisits in both groups of students was for the photos in set 3. On the basis of this, it can be concluded that the location of the photos is of great (unconscious) importance to students (both dyslexic and non-dyslexic ones). So, once again it is proved that locating photos outside a read text changed the values of eye-tracking metrics, and, as a consequence, weakened the visual interest in these AOIs.

Table 5 also shows a change in the number of revisits by both dyslexic and non-dyslexic students to box 1, i.e. a very important AOI, and to box 2, i.e. an unimportant one. In the case of box 1 , moving it closer to the text that was read caused a decrease in entry time and first fixation duration but it also increased the number of revisits to this AOI. And that was precisely the aim of the changes made to the sets. Similarly, moving box 2 further from the text resulted in a decrease in visual interest in it. This can be seen in the revisits count regarding it.

All the above mentioned parameters for eye movements characterize the way Polish secondary school students acted while completing the tasks. The most significant question, though, is if it anyhow 
influences the process of learning, here measured by the correctness of the given answers.

\subsection{Correctness of the answers}

Because set 1 and set 3 were identical from the point of view of their content, the given answers can be compared. In both sets participants were asked to complete exercise 2 - it consisted of reading the given text and choosing one proper ending/answer (out of a, b, c, d) to five sentences/questions that were given. Exercise 3 was matching five definitions that were given with 5 words highlighted in the text. The maximum number of points in every exercise was 5 . Answer correctness is shown in Figure 3.

In Figure 3 the difference in the answer correctness in both groups of participants can be noticed. In set 1 , the difference between dyslexic and non-dyslexic students equals $9 \%$ in favour of the latter ones. However, in set 3, which was devoid of pictures in the text area and of graphic elements, the difference between the groups became smaller. Non-dyslexic students gave $1 \%$ less correct answers but at the same time dyslexic ones improved their results - correctness of their answers was only $3 \%$ smaller. That means the changes introduced to set 3 helped dyslexic students be more effective from the point of view of the number of correct answers and did not decrease the results of non-dyslexic ones.

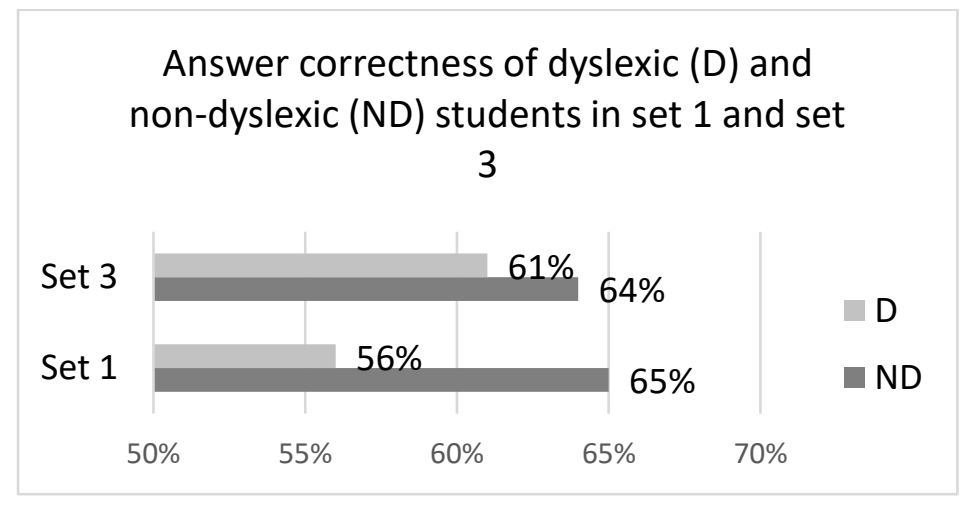

\section{Figure 3}

Correctness of the answers given by dyslexic and non-dyslexic students in both sets. Source: own. 


\section{Conclusions}

The above results are of great significance from the social point of view as they show that wise and conscious planning of the textbook layout can support particular groups of students in their work with the textbook, as well as with their final results. However, it should be further checked how to increase the results of dyslexic students and not to decrease the ones of non-dyslexic students at the same time.

The results of our study support the assumption that the way the textbook material is planned and designed on the page of the textbook is significant from the point of view of the way dyslexic and non-dyslexic students work with it and, finally, from the point of view of the results they achieve. It can be said that conscious design of such a page can be a help or a distractor. What is more, wise planning can stimulate the final results of especially dyslexic students, making them become as successful as non-dyslexic ones. And it is a crucial conclusion of a huge social value.

\section{References}

Amso, Dima, Sara Haas, Julie Markant (2014). "An eye tracking investigation of developmental change in bottom-up attention orienting to faces in cluttered natural scenes". Plos One 9/1: 1-7.

Andrychowicz-Trojanowska, Agnieszka (2018). Podręczniki glottodydaktyczne: Struktura - funkcja - potencjał $w$ świetle badań okulograficznych. Warszawa: Studia Naukowe.

Bogdanowicz Katarzyna, Maria (2011). Dysleksja a nauczanie języków obcych. Przewodnik dla nauczycieli i rodziców uczniów z dysleksją. Gdańsk: Harmonia.

Duchowski, Andrew (2007). Eye Tracking Methodology: Theory and Practice. Clemson: Springer.

Evans, Bruce J. W. (2001). Dyslexia and Vision. London: Wiley.

Habib, Michel (2000). "The neurological basis of developmental dyslexia; An overview and working hypothesis". Brain 123: 23732399.

Hanisz, Jadwiga (2005). "Podręcznik". In: Urszula Śmietana (ed.). Encyklopedia pedagogiczna XXI wieku. Vol. 4. Warszawa: Wydawnictwo Akademickie Żak. 
Holmqvist, Kenneth, Marcus Nyström, Richard Andersson, Richard Dewhurst, Halszka Jarodzka. Joost van de Weijer (2011). Eye Tracking: A Comprehensive Guide to Methods and Measures. New York: Oxford University Press.

Hotchkiss, Gord (2007). Eye Tracking on Universal and Personalized Search. Available at http://searchengineland.com/eye-trackingon-universal-and-personalizedsearch-12233. Accessed 14.07.2016.

Hotchkiss, Gord, Steve Alston, Greg Edwards (2005). Eye Tracking Study. Available at http://searchengineland.com/figz/wp-content/ seloads/2007/09/hotchkiss-eyetracking-2005.pdf. Accessed 14.07. 2016.

Jacob, Robert J. K., Keith S. Karn (2003). "Eye tracking in humancomputer interaction and usability research: Ready to deliver the promises". In: Jukka Hyönä, Ralph Radach, Heiner Deubel (eds.). The Mind's Eye: Cognitive and Applied Aspects of Eye Movement Research. Amsterdam: North-Holland, 573-605.

Lorigo, Lori, Maya Haridasan, Hrönn Brynjarsdóttir, Ling Xia, Thorsten Joachims, Geri Gay, Laura Granka, Fabio Pellacini, Bing Pan (2008). "Eye tracking and online search: Lessons learned and challenges ahead". Journal of the American Society for Information Science and Technology 59/7: 1041-1052.

Mitchell, Michael, Susan Wightman (2012). Typografia ksiażki: Podręcznik projektanta. Kraków: Wydawnictwo d2d.pl.

Nielsen, Jacob (2006). F-Shaped Pattern for Reading Web Content. Available at https://www.nngroup.com/articles/f-shapedpattern-reading-web-content-discovered/. Accessed 12.07.2016.

Pollak, David (2012). "Studenci z dysleksja w Wielkiej Brytanii". In: Marta Bogdanowicz (ed.). Dysleksja w wieku dorosłym. Gdańsk: Harmonia, 167-197.

Poole, Alex, Linden J. Ball, Peter Philips (2004). "In search of salience: A response time and eye movement analysis of bookmark recognition". In: Sally Fincher, Panos Markopolous, David Moore, Roy Ruddle (eds.). People and Computers XVIII - Design for Life: Proceedings of HCI 2004. London: Springer, 363-378.

Rayner Keith (1998). "Eye movements in reading and information processing: 20 years of research". Psychological Bulletin 124/3: 372422.

Tullis Tom, Bill Albert (2013). Measuring the User Experience: Collecting, Analyzing, and Presenting Usability Metrics. Elsevier. 
Agnieszka Andrychowicz-Trojanowska ORCID: 0000-0001-6657-8823

Uniwersytet Warszawski

Instytut Komunikacji Specjalistycznej

i Interkulturowej

ul. Szturmowa 4

02-678 Warszawa

Poland

a.andrychowicz@uw.edu.pl 